\title{
Implementasi Obrim (Option-Based Risk Management) Sebagai Framework Investasi Teknologi Informasi Perguruan Tinggi (Studi Kasus: Amik Labuhan Batu)
}

\author{
Marnis Nasution', ${ }^{1}$ Sentosa Pohan ${ }^{2)}$, Syaiful Zuhri Harahap ${ }^{3)}$ \\ Dosen Fakultas Sains dan Teknologi, Universitas Labuhanbatu \\ Email : marnisnst@gmail.com ${ }^{1)}$, sentosa_pohan@yahoo.com ${ }^{2}$, syaifulzuhriharahap@gmail.com ${ }^{3)}$
}

\begin{abstract}
Abstrak
Sistem C4I (Command, Control, Communication, Computer, and Inteligence) merupakan salah satu sistem pendukung keputusan yang banyak digunakan pada dunia militer. C4I bekerja dengan cara pengumpulan data-data real di lapangan melalui media komunikasi pada waktu nyata yang kemudian diolah dengan komputer yang memiliki kecerdasan buatan. Setelah diolah, luaran yang didapatkan adalah sinyal-sinyal command yang harus dilaksanakan. Di dalam dunia militer, sistem C4I ini terbukti bisa dihandalkan karena bisa menghasilkan respon keputusan yang cepat namun tetap berdasarkan data dan fakta yang lengkap, akurat, dan up to date. Beberapa penelitian telah banyak mencoba mentransformasikan sistem C4I dari dunia militer ke pemerintahan sipil. Seiring dengan perkembangan Teknologi Informasi dan Komunikasi, sistem C4I dapat ditransformasikan melalui perpaduan berbagai metodologi dan model Teknologi Informasi seperti data mining, documen management, knowledge management, sistem pakar, atau game theory. Model yang digunakan kemudian dikombinasikan melalui siklus Observasi, Orientasi, Keputusan, dan Tindakan (OOKT) sehingga bisa menghasilkan transformasi dasar C4I pada pemerintahan sipil. Hasil perpaduan ini akan terbentuklah model command system yang bisa digunakan untuk mengambil berbagai keputusan strategis di pemerintahan. Model yang terbentuk ini kemudian bisa diuji dalam menentukan kebijakan-kebijakan tertentu, yang dalam penelitian ini adalah penentuan besar tarif internet
\end{abstract}

\section{Kata kunci-Command Systems, Sistem Pendukung Keputusan, Sistem C4I}

C4I system (Command, Control, Communication, Computer, and Intelligence) is one of the decision support systems that are widely used in the military. C4I works in a way collection of real data in the field through communication media in real time which is then processed with computers that have artificial intelligence. After processing, the output obtained is the command signals that must be carried out. In the military world, this C4I system proven to be reliable because it can produce quick but steady decision responses based on complete, accurate and up to date data and facts. Several studies have tried to transform the C4I system from the military to civilian government. Along with the development of Information and Communication Technology, C4I systems can be transformed through a combination of various Information Technology methodologies and models such as data mining, document management, knowledge management, expert systems, or game theory. The model used is then combined through the Observation, Orientation, Decision, and Action (OOKT) cycle so that it can produce a basic transformation of C4I in civil government. The results of this integration will form a command system model that can be used to make various strategic decisions in government. This formed model can then be tested in determining certain policies, which in this study is determining the amount of internet tariffs

Key Word - Command Systems, Decision Sistem, Sistem C4I 


\section{PENDAHULUAN}

Sistem Informasi (SI) telah mengambil peran yang penting di dalam kelancaran bisnis dan transaksi suatu organisasi profit dan non profit. Namun terkadang organisasi belum mengetahui apa saja dan seberapa besar manfaat dari SI bagi organisasi, sehingga sering kali proyek SI tidak pernah dikembangkan secara maksimal. Nilai manfaat finansial tangible artinya dapat manfaat yang dapat dihitung, dengan satuan mata uang dari investasi proyek SI, sehingga organisasi dapat menghitung dengan rasio-rasio yang diinginkan, karena variable-variabel hitungannya jelas. Pengukuran nilai finansial SI dimaksudkan untuk mengetahui apakah suatu proyek SI yang dilaksanakan memberikan manfaat yang sesuai dengan biaya yang telah dikeluarkan. Untuk memperoleh hasil dan manfaat yang maksimal bagi suatu organisasi dalam melaksanakan dan menginvestasi proyek SI diperlukan suatu perencanaan yang matang.

Namun kenyataannya tidak ada korelasi yang pasti antara nilai uang yang diinvestasikan kedalam proyek SI dengan nilai ekonomis yang dihasilkan dari implementasi SI. Manfaat yang dihasilkan tidak pasti didapat setelah instalasi perangkat lunak, perangkat keras dan jaringan selesai di lakukan. Banyak hal ketidakpastian yang dapat mempengaruhi keberhasilan dari implementasi SI (Thorp,

2003). Berangkat dari isu tersebut maka Michel Benaroch, seorang professor dalam bidang Manajemen Sistim Informasi dari Syracuse University, New York, dalam penelitiannya yang dilakukan tahun 2001, mengajukan konsep OBRiM ( Options Based Risk Management) sebagai suatu metodologi atau kerangka kerja yang dapat digunakan sebagai panduan untuk menanalisa dimemaksimalkan nilai investasi pada proyek SI dan mengurangi risiko kegagalan akibat unsur ketidakpastian dari investasi (Benaroch, 2001). Kerangka kerja OBRiM diharapkan dapat menjawab dilema yang dihadapi banyak organisasi atau organisasi dala $\mathrm{m}$ melakukan investasi proyek SI dengan berbagai pilihan scenario options sedemikian rupa sehingga dapat ptimal mengatur risiko dan memaksimalkan nilai strategis organisasi.

Sebagian organisasi telah menerapkan manajemen risiko untuk menidentifikasi faktor risiko dan menentukan pilihan yang dapat mengatasinya. Namun cara tersebut masih dianggap belum optimal, karena tidak dapat menghubungkan antara perhitungan factor risiko dengan konsekuensi biaya dan manfaat dari investasi SI tersebut. Kelebihan dari penggunaan kerangka kerja

\section{LANDASAN TEORI}

\subsection{ROV Binomial Tree}

Istilah "Real Options" (RO) diperkenalkan pertama kali oleh Stewart C. Mayers dari Sloan

School of Management MIT pada tahun 1977, yang merujuk kepada aplikasi teori "option

pricing" dalam melakukan evaluasi investasi non finansial atau investasi nyata dengan menggunakan unsur pembelajaran dan fleksibilitas (Borison, 2003). Konsep dasar dari 
ROV adalah fleksibilitas untuk masa depan. Perhitungan ini memperhatikan ketidakpastian situasi yang terus menerus. ROV merujuk pada kenyataan bahwa organisasi memiliki hak untuk mengelola asetnya. Terdapat dua kombinasi yang harus dimiliki bila menggunakan metode ini yaitu adanya ketidakpastian yang berkaitan dengan aliran dana proyek di masa depan dan adanya fleksibilitas manajemen untuk merespon ketidakpastian yang terjadi.

ROV memberikan keuntungan dimana estimasi terhadap proyek dapat dilakukan dengan lebih akurat. Metode ini merupakan pendekatan yang lebih kompleks untuk melakukan penilaian dan pengambilan keputusan dibanding pendekatan Net Present Value (NPV). Terdapat sejumlah manfaat lainnya bila menggunakan metode ROV ini, antara lain (Gilbert, et al, 2004) :

1. Dorongan terhadap perubahan perhatian para pembuat keputusan dari prediksi masa depan secara menyeluruh seperti pada pendekatan NPV menjadi identifikasi apa yang dapat atau seharusnya dilakukan untuk merespons perubahan.

2. Memfokuskan perhatian pihak manajemen pada respon secara optimal pada masalah ketidakpastian dan perubahanperubahannya.

3. Menyediakan kemampuan estimasi bagi para pengambil keputusan terhadap tingkat optimal dari fleksibilitas yang terjadi.
Teknik-teknik yang digunakan untuk mendapatkan nilai RO sesungguhnya merupakan turunan langsung dari teknik valuasi yang digunakan pada Financial Options. Metode yang digunakan diantaranya yaitu dengan permodelan Black Scholes, diperkenalkan oleh Fisher Black dan Myron Scholes pada awal 1970, dan permodelan Binomial. Permodelan Binomial diperkenalkan oleh John Cox, Stephen Ross dan Mark Rubinstein pada tahun 1979 sebagai turunan dan bentuk penyederhanaan dari permodelan Black-Scholes (Wikipedia).

Kerangka kerja OBRiM menyarankan penggunaan metode Binomial Tree untuk memberikan kemudahan dalam menghitung nilai RO pada tiap konfigurasi options yang terdiri atas beberapa tahapan options dan eksekusi. Metode Binomial Tree merupakan representasi grafis dari kemungkinan nilai dari RO pada titik dan periode waktu yang berbeda. Dalam perhitungan RO, terdapat sejumlah parameter yang menentukan nilai RO, yaitu (Brach, 2003):

1. Probabilitas (q)

Merupakan parameter untuk mengukur tingkat keberhasilan dari setiap fase. Pada metode

compound options, tingkat keberhasilan (q) sangat menentukan nilai $R O$. Nilai q ini haruslah $\leq 1$.

2. Probabilitas Bebas Risiko (p)

Merupakan sebuah fungsi dari nilai keuntungan yang dihitung saat ini. Probabilitas bebas

risiko (Risk free probability) ini merujuk pada pembayaran yang diharapkan dan discount dari pembayaran yang diharapkan untuk 
harga saat ini dengan menggunakan suku bunga bebas risiko. Dengan kata lain, risk free probability (p) merupakan nilai q pada keadaan bebas risiko. Rumus yang digunakan untuk menghitung nilai ini adalah :

$$
P=\frac{\left(1-r_{j}\right) V_{\varepsilon}-V_{\min }}{V_{\min }-V_{\min }}
$$

3. Corporate discount rate $(\mathrm{Rc})$

Merupakan parameter untuk merefleksikan pengembalian (return) yang diinginkan para investor dengan mengambil acuan pada harga saham yang diperdagangkan secara publik dengan tingkat risiko dan pembayaran yang sama dengan proyek yang tengah dijalankan.

4. Risk free rafe (suku bunga bebas risiko) (rf)

Return on project yang diminta dan biasanya didasarkan pada suku bunga bebas risiko. Suku bunga bebas risiko didapat melalui observasi terhadap suku bunga bank at au suku bunga SUN (Surat Utang Negara). Pada investasi Teknologi Informasi (TI) berlaku hal yang sama.

5. Biaya (cost) per fase (K)

Merupakan perkiraan biaya yang dibutuhkan untuk setiap fase. Perkiraan biaya ini dapat berubah mengikuti perubahan sesuai dengan situasi yang terjadi.

6. Waktu per fase ( $t$ )

Merupakan perkiraan waktu yang dibutuhkan untuk menyelesaikan satu fase.

7. Nilai RO

Nilai RO terbagi dua, yaitu RO Call (C) dan RO Put (P).. C merupakan hak dan bukan kewajiban dari pemegang aset untuk membeli aset dengan harga yang telah disepakati sebelumnya dan pada jangka waktu tertentu. Sementara $\mathrm{P}$ adalah hak dan bukan kewajiban pemegang aset untuk menjual aset dengan kesepakatan harga yang telah ditentukan sebelumnya dan pada jangka waktu tertentu.

Berdasarkan tipe options-nya, nilai C dan $\mathrm{P}$ dimodelkan kedalam persamaan sebagai berikut

a. Options Defer

(Menangguhkan investasi):

$C=\frac{p . x \% \cdot V_{\max }+(1-p) X \% \cdot V_{\min }}{(1+r f)^{t}}-$

$K(1+r f)^{t}$

Dimana $\quad \mathrm{x}$ merupakan

persentase pengurangan

nilai investasi bila

investasi ditangguhkan.

b. Options Abandon

(Menghentikan investasi) :

Options menghentikan

investasi termasuk kedalam

Put Options, dengan nilai P :

$\frac{p\left(-V_{\min } x \%+S\right)+\left(-V_{\min } x \%+S\right)}{(1+r f)^{t}}-$

$K(1+R c)^{t}$

-......(2.3)

Dimana $\mathrm{S}$ merupakan nilai aset yang dapat diselamatkan dari investasi yang sudah dilakukan sebelum menjalankan options abandon

c. Options pengembangan investasi

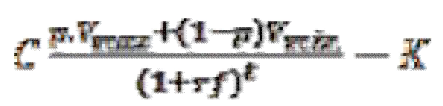

8. Nilai Aset yang diharapkan (Expected Asset Value) (Ve)

Merupakan nilai aset yang diharapkan didapat pada setiap fase. Nilai ini diambil berdasarkan perhitungan probabilitas keberhasilan dengan nilai aset maksimum dan minimum yang didapatkan. Rumus untuk parameter ini adalah $\mathrm{Ve}=\mathrm{q} . \mathrm{V} \cdot \mathrm{Max}+(1-$ q).Vmin

9. Nilai Maksimum. (V max ) 
Merupakan nilai investasi maksimum yang diprediksi akan didapat saat skenario options berhasil dijalankan. Nilai ini merupakan fungsi dari probabilitas keberhasilan. Bila probabilitas keberhasilan tinggi, maka nilai maksimum yang diharapkan juga akan tinggi dan begitupula sebaliknya. 10. Nilai Minimum (Vmin)

Merupakan nilai investasi minimum yang didapat berdasarkan skenario terburuk. Nilai ini juga merupakan fungsi dari probabilitas keberhasilan 1q.

\section{METODE PENELITIAN}

\subsection{Kerangka Kerja OBRIM}

OBRiM merupakan suatu kerangka kerja yang digunakan untuk membuat options strategis dari rencana investasi TI dalam skala besar dan ber-risiko tinggi (Benaroch, Jeffery, Kauffman, Sandeep S, 2007). Kemunculan OBRiM berangkat dari dilema yang dihadapi banyak organisasi dalam bagaimana menyusun langkah investasi TI sedemikian rupa sehingga dapat secara optimal mengatur risiko dan memaksimalkan nilai strategis organisasi. Beberapa pilihan langkah investasi TI yang dapat digunakan diantaranya, implementasi sekaligus dari investasi TI, implementasi bertahap, atau membuat proyek uji coba terlebih dahulu yang akan diikuti dengan implementasi TI keseluruhan setelah proyek uji coba dinilai berhasil. Setiap pilihan strategis tersebut tentunya membutuhkan kajian dan pertimbangan yang matang (Benaroch, Lichstenstein, Robinson, 2006).

$\begin{array}{lcr}\text { Sebagian } & \text { organisasi } \\ \text { menerapkan } & \text { kajian manajemen }\end{array}$ risiko untuk mengidentifikasi faktor risiko dan membuat rencana mitigasi risiko. Namun cara tersebut dianggap belum optimal, karena tidak dapat menghubungkan antara perhitungan faktor ketidakpastian risiko dengan konseksuensi biaya dan manfaat dari investasi (Benaroch, Lichst enstein, Robinson, 2006). Kerangka kerja OBRiM mengisi kesenjangan tersebut dengan penggunaan ROV. Penggunaan ROV dianggap tepat karena dapat memberikan nilai fleksibel yang digerakkan oleh kemunculan risiko. Lebih lanjut, OBRiM menemukan kombinasi ROV yang paling efektif untuk diterapkan kedalam investasi TI sehingga dapat secara optimal mengontrol risiko dan memaksimalkan manfaat investasi (Benaroch, Lichstenstein, Robinson, 2006).

Logika kerja OBRiM adalah mengidentifikasi risiko dari investasi $\mathrm{TI}$, dan menanamkan nilai RO kedalam investasi TI tersebut, sehingga ketika suatu risiko yang teridentifikasi diawal itu benar-benar muncul, nilai RO dapat memberikan masukan fleksibilitas pada keputusan dari manajemen. Kerangka kerja OBRiM menggunakan teori ROV untuk menghitung konsekuensi moneter dari risiko, menghitung fleksibilitas dalam nilai RO, dan mengaitkan nilai tersebut ke nilai bersih dari investasi. Kadang-kadang lebih dari satu kombinasi RO dapat mengontrol risiko yang mempengaruhi investasi TI secara konsisten dalam perspekti

finansial organisasi. Jika masingmasing kombinasi tersebut memiliki nilai biaya yang berbeda, kerangka 
kerja OBRiM dapat membantu dalam menemukan kombinasi RO yang paling efektif dan dapat digunakan untuk mengontrol risiko dan memaksimalkan nilai investasi (Benaroch, Jeffery, Kauffman, Sandeep S, 2007).

Prinsip OBRiM (Benaroch, Jeffery, Kauffman, Sandeep S, 2007):

1. ROV merupakan strategi level tinggi dalam

mengelola risiko. Beberapa dari options dapat digolongkan sebagai strategi mitigasi, misalnya, membuat prototipe dan membatalkan investasi. Options yang lain adalah menjalankan fleksibilitas untuk menghasilkan langkah mitigasi risiko secara bertahap yang bergantung pada kemunculan dari risiko.

2. Fleksibilitas harus secara proaktif ditanamkan kedalam investasi TI dengan didasari risiko tertentu yang harus dikontrolnya. OBRiM mengajukan pemetaan risiko dan options untuk menentukan RO mana yang akan digunakan untuk risiko TI tertentu. Misalnya, untuk mengontrol risiko mengenai ukuran dan kompleksitas dari proyek, options pengembangan bertahap, atau melakukan alih daya ke pihak ketiga mungkin lebih relevan untuk digunakan, dibandingkan options penundaan atau menghentikan proyek tersebut.

3. RO yang dipetakan kedalam risiko akan memunculkan alternatif konfigurasi dari investasi. Masing-masing konfigurasi memiliki kombinasi RO yang berbeda- beda.

4. Kombinasi yang berbeda dari RO akan mempengaruhi nilai investasi TI, karena masing- masing kombinasi dapat mengontrol risiko yang sama pada derajat yang berbeda, dan masing-masing kombinasi tersebut juga dimungkinkan memiliki nilai biaya yang berbeda. Nantinya dari kombinasi konfigurasi tersebut akan ditemukan satu konfigurasi yang paling menguntungkan secara ekonomis

OBRiM merumuskan Empat langkah analisis yang dibangun dan "analisis kasus dasar" yang spesifik untuk investasi TI (lihat gambar 2.1). Empat Langkah analisis tersebut adalah (Benaroch, Jeffery, Kauffman, Sandeep S, 2007):

1. Analisis Risiko : Mengidentifikasi risiko yang muncul pada investasi

2. Identifikasi Options : Melakukan pemetaan risiko ke solusi RO yang sesuai untuk di tanamkan ke investasi sebagai media mitigasi risiko

3. Mendesain konfigurasi investasi : Mendesain konfigurasi investasi yang masuk akal dengan menggunakan rangkaian options yang diidentifikasi pada tahap sebelumnya

4. ROV : Menentukan nilai NPV yang telah ditambahkan nilai fleksibilitas RO untuk tiap konfigurasi investasi dan memilih konfigurasi yang paling bernilai.

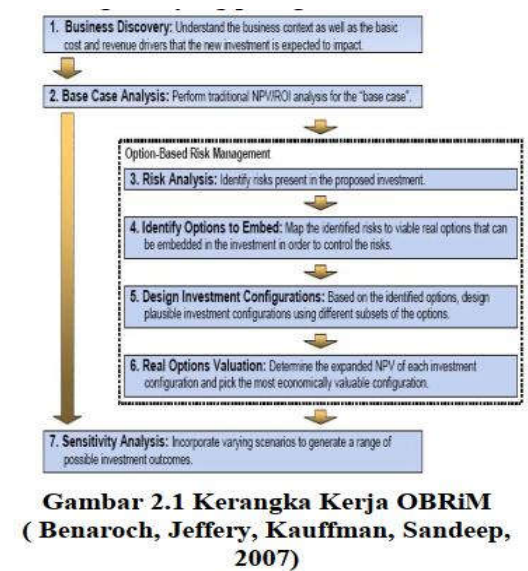

3.2 Analisis Resiko dan Options 


\begin{abstract}
Analisis risiko dilakukan dengan mengidentifikasi dan mengukur risiko. Secara umum langkahlangkah dalam identifikasi dan pengukuran risiko adalah sebagai berikut:
\end{abstract}

1. Mengidentifikasi risiko dan mempelajari karakteristik risiko tersebut

2. Mengukur risiko tersebut, melihat seberapa besar dampak risiko tersebut terhadap kinerja organisasi, dan menentukan prioritas dari risiko tersebut. Kaidah kajian risiko merujuk pada siklus manajemen risiko (Lihat gambar 2.2).

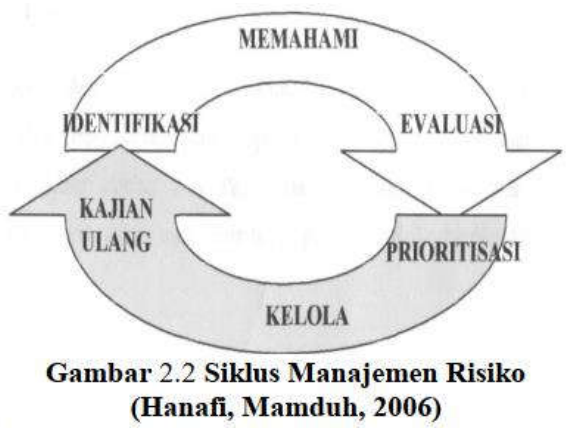

Langkah pertama yang harus dilakukan dalam manajemen risiko dalah melakukan identifikasi risiko. Selanjutnya, hasil identifikasi risiko harus dipahami dan dievaluasi untuk dapat merumuskan metode pengelolaan risiko yang tepat. Kemudian dilakukan prioritisasi risiko dengan mengkuantifikasi tinggi rendah probabilitas kemunculan risiko dan dampaknya terhadap kinerja organisasi. Pengelolaan atau pembuatan rencana mitigasi untuk mengurangi dampak risiko difokuskan pada risiko yang dianggap paling relevan (misal memiliki dampak dan probabilitas yang besar) atau berdasarkan prioritas. Langkah terakhir adalah kajian ulang dengan terus mengevaluasi ulang langkahlangkah yang sudah dilakukan untuk meningkatkan efektivitas manajemen risiko.

Identifikasi risiko adalah proses untuk memahami kejadian apa saja yang berpotensi kelangsungan proyek. Identifikasi risiko yang baik akan memudahkan kita dalam mengelola risiko tersebut. Ada beberapa alat bantu untuk mengidentifikasi risiko, diantaranya dengan menggunakan Risk Breakdown Structure (RBS). RBS merupakan daftar potensi risiko proyek yang disusun secara hirarki berdasarkan kategori tertentu. Schwalbe membagi risiko pada proyek TI kedalam 4 kategori dasar (Schwalbe,2007), yaitu:

1. Risiko Organisasi

2. Risiko Bisnis

3. Risiko Manajemen Proyek

4. Risiko Teknis

Dari 4 kategori dasar tersebut kemudian diturunkan kembali faktor risiko apa yang berperan dalam implementasi suatu proyek TI secara spesifik ke organisasi obyek studi kasus (Lihat gambar 2.3). Penggunaan RBS akan sangat membantu tirn pengembang proyek dalam mempertimbangkan sumber risiko berdasarkan kategori tersebut.

Pengukuran dan prioritisasi risiko dilakukan dengan mengkuantifikasi tinggi rendah probabilitas kemunculan risiko dan dampaknya terhadap kinerja organisasi. Untuk memudahkan prioritisasi risiko dapat dilakukan 
dengan memetakan faktor risiko kedalam matriks Dampak-Probabilitas (Lihat gambar 2.4). Matrik Dampak Probabilitas dibagi menjadi 3 kategori, yaitu rendah, sedang dan tinggi. Matrik DampakProbabilitas menampilkan faktor risiko dengan probabilitas relatif pada satu sisi dari matrik dan dampak relatif dari risiko pada sisi yang lain. Dengan memperhatikan pemetaan risiko tersebut, tim pengembang proyek akan dapat melihat risiko mana yang perlu diprioritaskan atau mendapat perhatian lebih.

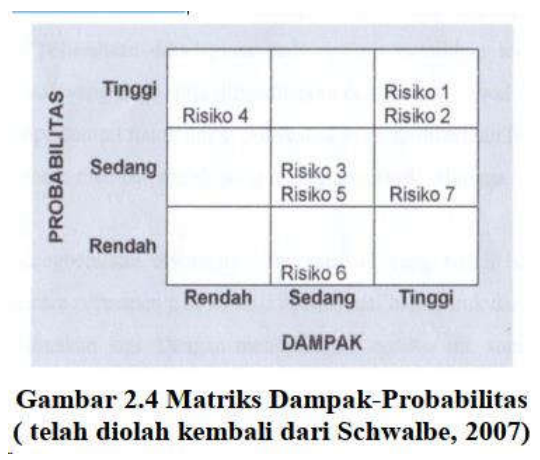

Pada kerangka kerja OBRiM, rencana mitigasi risiko di wujudkan dalam bentuk options atau pilihan investasi. Options investasi pada OBRiM merujuk pada options teori options pricing dan penelitian yang dilakukan oleh M.Benaroch, pada tahun 2002 yang memodifikasi options tersebut menjadi lebih spesifik untuk investasi TI. Options tersebut adalah sebagai berikut (Benaroch,2002):

1. Defer (Menangguhkan

investasi

2. Stage (Investasi bertahap)

3. Explore (Menjelajahi investasi) : Investasi TI dapat direalisasikan dalam skala prototipe atau proyek percontohan. Jika proyek percontohan tersebut berhasil, skala investasi TI dapat ditingkatkan dengan membuat investasi lanjutan.

4. Alter Scale (Merubah ruang lingkup investasi).

5. Abandon (Menghentikan investasi) .

6. Outsourcing (Sub-kontrak investasi ke pihak ketiga): .

7. Lease (Menyewa investasi) : .

8. Compound (Menggabungkan pilihan investasi) :

9. Strategic Growth

(Pertumbuhan yang bernilai strategis): .

Relevansi antara risiko dan options didapat dengan membuat pemetaan risiko dengan options yang dapat mengontrolnya. Merujuk pada penelitian yang dilakukan oleh Benaroch pada tahun 2002 (Benaroch,2002), pemetaan antara risiko dan options tersebut harus didasari oleh pemikiran bahwa perbedaan tahapan dari siklus investasi akan menimbulkan risiko dan options mitigasi risiko yang berbeda.

\section{HASIL DAN PEMBAHASAN}

Penelitian ini dilakukan di AMIK Labuhan Batu, dengan menggunakan metode:

1. Study Literatur: Studi mengenai \

Penggunaan ROV ( Real Options Valuation ) dan Kerangka kerja OBRiM ( Obtions- Based Risk management ), untuk membuat scenario investasi. 
2. Wawancara : dilakukan pada manajemen AMIK Labuhan Batu terkait dengan proyek SIT.

3. Kuesioner:

untuk mengidentifikasi resiko proyek dan prioritas dampak dari resiko tersebut.

\subsection{Analisis Ranah Bisnis}

Untuk tahap analisis ranah bisnis yang akan diteliti adalah ranah bisnis Penerimaan Mahasiswa Baru dan Pengisian KRS. Juga dikaji tentang proses bisnis secara menyuluruh tentang organisasi AMIK Labuhan Batu dan proyek Sistem Informasi AMIK Labuhan Batu.

\subsection{Nilai Investasi}

Nilai investasi yang akan dikaji dalam penelitian ini dibatasi pada investasi terkini, yakni Proyek Pengembangan Aplikasi dan Mobile Apps untuk tahun 2017 total investasi sejumlah Rp.428.010.000 dengan NPV sebesar Rp 2.179.090.382,94.

\subsection{Analisis Resiko}

Analisis Resiko dilakukan dengan menggunakan Tabel Probabilitas Keberhasilan dan Tahapan Investasi; yakni Tahap Pengakuan 0.64, Tahap Pembangunan 0.5 dan Tahap Operasional 0.37

\subsection{Analisis Option}

Kerangka kerja OBRiM, memberikan 9 Options terkait dalam resiko investasi, yakni: Options Defer (menangguhkan investasi), Stage (Investasi Bertahap), Explore (Menjelajahi Investasi lewatprototype atau membuat project percontohan), Abandon (Menghentikan Investasi), Oursourcing (Sub- kontrak investasi ke pihak ketiga), Lease (Menyewa Investasi), Compound (Menggabungkan pilihan investasi), dan Strategic Growth/Expand (Pertumbuhan yang bernilai strategis), 9 options kemudian dianalisis kemungkinan penggunaannya dengan melakukan wawancara dan FGD dengan manajemen UPT TIK, selaku pengelola proyek

Setelah nilai RO dari semua kondisi pada konfigurasi scenario investasi Proyek Pengembangan Aplikasi dan Mobile Apps AMIK Labuhan Batu ditentukan, langkah selanjutnya adalah mencari nilai RO dari masing-masing jalur scenario. Nilai RO keluaran dari jalur scenario didapat dari menjumlahkan nilai RO tiap kondisi pada satu jalur scenario

Tabel 4.25 Nilai RO dari Tiap Jalur Skenario

\begin{tabular}{|c|c|c|}
\hline Skenario & Kondisi & Nilai RO \\
\hline $\mathrm{S} 1$ & $1+2$ & $\begin{array}{l}\text { Rp } 3.153 .084 .779+ \\
\text { Rp } 1.633 .244 .827 \\
=R p 4.786 .329 .606\end{array}$ \\
\hline $\mathrm{S} 2$ & $1+2^{\prime}$ & $\begin{array}{l}\text { Rp } 3.153 .084 .779+ \\
\text { Rp 462.332.874 } \\
=R p 3.615 .417 .653\end{array}$ \\
\hline S3 & $\begin{array}{l}1,3+ \\
4+5\end{array}$ & $\begin{array}{l}\text { (-) Rp } 323.896 .090+ \\
\text { Rp 461.145.770+ Rp } \\
461.145 .770 \\
=\text { Rp } 1.246 .187 .630\end{array}$ \\
\hline S4 & $\begin{array}{l}1 '+3+4 \\
+5\end{array}$ & $\begin{array}{l}\text { (-) Rp } 323.896 .090+ \\
\operatorname{Rp} 461.145 .770+R p \\
461.145 .770+R p \\
902.572 .080= \\
\operatorname{Rp} 2.148 .759 .710\end{array}$ \\
\hline S5 & $\begin{array}{l}1^{\prime}+3+ \\
4,\end{array}$ & $\begin{array}{l}\text { (-) Rp } 323.896 .090+ \\
\operatorname{Rp} 461.145 .770+\operatorname{Rp} \\
557.923 .380 \\
=\operatorname{Rp} 695.173 .060\end{array}$ \\
\hline S6 & $1^{\prime}+3^{\prime}$ & $\begin{array}{l}\text { (-) Rp } 323.896 .090+ \\
0 \\
=R p-323.896 .090\end{array}$ \\
\hline
\end{tabular}

Dapat dilihat pada Tabel 4.25 nilai RO tertinggi dimiliki oleh jalur scenariol. Dengan demikian langkah scenario yang dapat diambil manajemen AMIK Labuhan Batu untuk memaksimalkan investasi Proyek Pengembangan 
Aplikasi dan Mobile Apps AMIK Labuhan Batu adalah

1. Melaksanakan proyek percontohan

2. Proyek percontohan kemudian dilanjutkan dengan pelaksanaan proyek secara keseluruhan

3. Melakukan tinjauan ulang setelah proyek keseluruhan dilaksanakan.

\section{KESIMPULAN}

Beberapa kesimpulan yang didapat dari penelitian ini adalah:

1. Konfigurasi scenario pada penelitian ini memiliki dua jalur-utama, yakni scenario untuk menjalankan proyek percontohan sebelum implementasi proyek keseluruhan dan scenario untuk menunda investasi, dan menjalankan pengembangan secara bertahap.

2. Hasil kajian menunjukkan bahwa scenario melaksanakan proyek percontohan dan kemudian melanjutkan proyek secara bertahap adalah scenario yang memberikan manfaat investasi yang paling besar, karena memiliki resiko yang paling kecil.

3. Teknik perhitungan Real Options Value dapat dikombinasikan dengan Tabel Identifikasi Manfaat Bisnis TI guna memudahkan proses identifikasi manfaat dan resiko dari implementasi proyek TI.

\section{DAFTAR PUSTAKA}

Borison, Adam, Real Options Analysis. 2003." Where Are the Emperor Clothes?“"
Benaroch, M , 2001. Option-Based Management of Technology Investment Risk, IEEE Transactions on Engineering Management, Vol. 48, No. 4, pp. 428-444, November,

B enaroch M., 2002. Managing Information Technology Risk: A Real Options Perspective,Journal of Management Information System, May 28,2002.

Benaroch,M , Lichtenstein, Y, Robinson K, 2006 Real Options In IT Risk Management: An Empirical Validation of Risk-Options Relationship, Journal Of Management Information Systems, February.

Benaroch M., Jeffery M., Kauffman R J.,Sandeep S., 2007. OptionBased Risk Management: A Field Study Of Sequential IT Investment Decisions, Journal Of Management Information Systems, 24,2, Fall.

Eko Tri Prasetyo, 2006 Kajian Manfaat Ekonomis Pemilihan Strategi Sentralisasi Aplikasi pada Proyek Radical Marketing Dengan Real Options : Studi Kasus PT. AOP, Tesis Magister Teknologi Informasi; Universitas Indonesia.

Amelia Nastuti, Syaiful Zuhri Harahap. (2019). TEKNIK DATA MINING UNTUK PENENTUAN PAKET HEMAT SEMBAKO DAN KEBUTUHAN HARIAN DENGAN MENGGUNAKAN ALGORITMA FP-GROWTH (STUDI KASUS DI ULFAMART LUBUK ALUNG), 7(3), 111-119. Hanafi,Mamduh.2006. Manajemen Risiko, UPP STIM YKPN, 